\title{
LITERARY BIOGRAPHY: NARRATIVE FEATURES
}

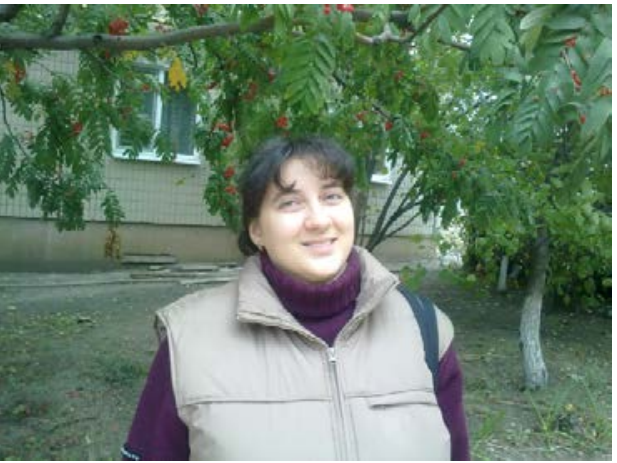

(C) Tetiana Cherkashyna, Doctor of Philology, Associate Professor, Full Professor of the Department of Romance Philology and Translation of the School of Foreign Languages, V. N. Karazin Kharkiv National University, Svobody sq., 4, Kharkiv, Ukraine, 61022, tetiana.cherkashyna@karazin.ua

The article is devoted to the study of narrative features of the literary-biographical prose. Literary biography is the one of structural-thematic variants of the documentary literature. It consists of several subspecies which differ by the main subject of the image, the completeness of the life path of the outstanding personality, the degree of interest to the creative heritage of the main character, the dominant aspect, the veracity of the playback image of the outstanding personality.

Literary-biographical text is a system that consists of a main text and a peritext. The peritext is secondary to the main text and it performs an auxiliary function in the perception and interpretation of the main text. The peritext consists of three main parts: pretext (name (alias) of the author, title, subtitle, dedication, epigraph to the entire work, Preface), pagetext (the epigraphs to parts, books, chapters; internal and footnotes; internal headers) and aftertext (notes after text, epilogue, afterword, marking the date and place of writing works, reviews, apps, content).

The main text of literary biography is constructed for well-established schemes. Different types of literary-biographical writing have their narrative and structural features. Among the leading types are distinguished content-semantic literary biographies (plot-event, associative-psychological) and formalized one.

Key words: literary biography, narration, text, peritext, author, reader.

Literary-biographical prose is known since the era of antiquity, but it does not lose its urgency on the beginning of XXI century. Every year there are more vivid examples of this type of documentary literature. 
At the beginning of the last century there was a dispute regarding the dominance between fictional and non-fictional literary biographies, and today we have wide genre-stylistic and typological varieties of literary-biographical prose.

Increasingly, authors are beginning to depart from the generally accepted norms and principles of the literary-biographical works, the main ones are the veracity of the image of outstanding personality literary figure, high literary of narration, relying on authentic documents and facts, dispassion of biographer, deep dive into the psyche of the main character, and others; and pay attention to alternative and fictitious biographies, which are organically intertwined truth and fiction.

Much more often, literary biographers are playing with the form of literary biography, which can appear not only in the form of logically consistent text according to a clear chronology of events but and mosaic set of text blocks which specify and complement each other. A typical feature of the modern literary biographies becomes the intertwining of the biographies of real historical figures with fictional characters life. The real or alternative biography of the real person becomes the key to understanding the motivation of the actions and behavior of fictional characters.

The appearance of diverse literary biographies (canonical and noncanonical), in turn, can not attract the attention of many researchers of this type of documentary literature. See for this reason (Галич, 2013; Галич, 2015; Карачова, 2016; Черкашина, 2009; Шевердіна, 2014; Boyer-Weinmann, 2005; Cline, and Angier, 2010; Life Writing, 2007, and others).

There are several types of literary biographical prose, which differ

- the main subject of the image (as «traditional or plot-event» literary biographies (Галич, 1984: 10), in which «the role of the author's speculation is minimal, and the emphasis is on the literary analysis of documented events of the life and deeds of the hero» (Галич, 1984: 10); and «associative-psychological» ones (Галич, 1984: 10), in which «dominates the artistic exploration of the psychology of the inner world of the hero» (Галич, 1984: 11);

- the completeness of the life path of the outstanding personality (there are a complete biographies, which comprehensively reflect the entire details the life and career of the protagonist from birth to death; and partial biographies that appeal only to a specific, usually bright, stage of life, an outstanding personality); 
- the degree of interest to the creative heritage of the protagonist (e.g., Anglo-Saxon literary biographies, «in which we have a lot of quotes of the texts by the writer» (Биографии и контрбиографии, 2000: 278); and factual ones, «which do not directly relate to the work of the writer» (Биографии и контрбиографии, 2000: 278);

- the dominant aspect (in this case, we identify content-semantic literary biographies in which focuses on informative saturation of the works of new or little-known facts of the life of the protagonist of literary biography; and formalized literary biographies in which the main focus is on the dynamism of form and the unusual design of the text);

- the veracity of the playback image of the outstanding personality (the canonical, or real life stories that go beyond the usual interpretation of this image and is based on the criterion of the truth of the image, drawing on authentic biographical documents and facts; and non-canonical, or alternative, in which the author for some reason reflects the unconventional, at times controversial, point of view at the image of a person, departing from the criterion of the veracity of the depiction of a concrete historical personality).

Literary-biographical text is presented as a system consisting of peritext and main text.

Literary-biographical peritext consists of three parts: pretext (that includes the name (alias) of the author, title, subtitle, dedication, epigraph to the entire work, preface), pagetext (the epigraphs to parts, books, chapters; internal and footnotes; internal headers) and aftertext (notes after text, epilogue, afterword, marking the date and place of writing works, reviews, apps, content).

Peritext is secondary to the main text and performs a supporting role in the perception and interpretation of the main text, displaying a high degree of authorial presence.

Author's name (alias) establishes narrative contact with the reader, interests him, and forms the reader's horizon of expectations. Mandatory narrative requirement is that the author's name is not identical to the name of main character. The author's name can be as a guarantor of the further narration, especially if we are talking about the names of famous writers who created a series of literary-biographical works, develop your own style of writing literary biographies; about the names of famous writers who have created only one literary-biographical works that is not beyond the limits of 
their individual creative style; about the names of known translators, journalists, scientists etc. who has created one literary biographical work. Thus, the name (alias) of the author predicts the future style of narration and acts as a guarantor of its quality.

The title appears to be the hallmark of the literary-biographical works and is responsible for narrative contact between author and reader. Characteristic feature is that most of the titles are directly or indirectly indicate the direction of further biographical narrative (in particular by stating in the title the name of the protagonist of literary biography or a certain leitmotif that causes a persistent association with the person; the use of tokens to refer to the biological time of human existence; the use of quotes from creativity of the hero, etc.). Consequently, the reader's «horizon of expectations» is formed at header level. In the case of hard decoding descriptive header to help the reader comes in the subtitle, which acts as an auxiliary means of revealing the author's intentions.

Referring to the subtitle, the reader has the opportunity to specify or to decrypt the primary header, to learn about the genre and stylistic features of the work, to obtain additional information concerning the main character of literary biographies (what's his name, profession, sphere of creative activity, etc.).

At the level of the preface we have the narrative contract between writer and reader. It is guaranteed to the reader the truthfulness and high literary level of the further narrative, reveals the secrets of the author's text, formed the reader's horizon of expectations. A typical feature is a prior acquaintance with the identity of the main character (in the case with the author's introductions) and the author of the literary biographies (in introductions on behalf of others), justification of the choice of the hero, the explanation of the source base and the history of writing biographies, an explanation of the creative manner of the literary biographer (in introductions on behalf of others), etc.

The system of internal headers, which is an optional component that details the common header and helps to structure the narrative. Mostly the reader has to deal with two types of internal headers: transparent (with respect to the further content of the work) internal headers that are added to the system on the same principle (e.g. the principle of classification, periodization, etc.) or of mixed type; and figurativelypoetic internal headers that do not contain direct information on the direction of biographical works. 
Notes help to describe the content of the main text. Typically, the reader deals with three types of notes, each of which has its own functionality. We are talking about neutral, with the position of the author's influence on the reader, notes (translated, linguistic, ethnographic, historical, biographical, bibliographical, etc.), the purpose of which is to transfer and refine the use of foreign words, phrases, phraseological expressions, a specification referred to in the text ethnographic or historical realities, providing information about the persons whose names are used in the text, sources of the work; metanarrative notes, the main purpose of which is extended to comment on events at the expense of input of comments from other interpreters; and accent more notes the main purpose of which is to influence the reader's perception of the work through direct request of the author to the reader.

Applications perform the function of specification and help you get the most play, the biography of an outstanding personality, to summarize the essential biographical facts mentioned in the work, provide information on development topics by other researchers.

Thus, at the level of peritext, the title author prepares the reader to perceive the main text of literary biography, directs its maze of biographical narrative, helps to understand the main text of the literary biography, generates the correct (according to author) the interpretation of the image of the protagonist.

The main text of literary biography built on a well-established pattern and each of the types of literary-biographical writing has its own narrative and structural features.

For the content-semantic literary biographies typical is to focus on information and training direction of work. This is a comprehensive biography, which thoroughly cover the life and work of an outstanding personality on the background of the modern era and focus on the content-semantic part of the work. The authors of this kind of literary biography provide exhaustive biographies of informative direction, not forgetting the ethical or the aesthetic education of readers. Mostly, the author recedes into the background and holds the position of «official scribe» (Современное зарубежное литературоведение, 1999: 156) and historiographer that reserves the role of the invisible meticulous researcher and a good psychologist who collects material related to the main character, analyzes it thoroughly, visits the places which are somehow connected with the life and work of the hero, meets with people who are personally acquainted with him (if we are talking about the biography of the contemporary) and provides trustworthy, reliable, documented information to the reader. 
In plot-event type of the content-semantic biographies (examples of which are «Emile Zola» by Henri Troyat, «Prométhée ou La vie de Balzac» by Andre Maurois, «Olympio ou La vie de Victor Hugo» by Andre Maurois, «Byron» by Phyliss Grosskurth, «Oscar Wilde» by Jacques de Langlade, «Voltaire» by Victor Koptilov, and others) the leading role is played by the figure of the main character, his personal, creative and public life that occurs with representation of its era, its moods, trends and challenges. The story is entrusted to conduct the all-knowing narrator with an unlimited vision in the form of the third person singular that is not opposed to the author of the work and acts as primary narrative instance.

The author and the reader at the textual level can be expressed not only implicitly, but also explicitly. The author in the text may be a certain distance and can't influence directly on the reader's perception of the work. However, more typical is the direct authorial intervention in the biographical narration (when the author appears as a credible researcher, witness of the events described directly or actor) to help the reader to understand the intricacies of the narrative, right to express the author's position or to present purely the author's achievements, to tell about a personal impression of the hero, a contemporary of the author, or tell about the author's journey in the footsteps of the hero of searching for a new or unexplored facts of his biography. In the two latter cases, the author may be expressed explicitly.

The reader is thus presented as an outside observer, diligent student that he fully trusts the author, or in the role of accomplice in the author's narration. It can be text or at a certain distance from the author and story, or as close to them due to the change of the text strategy and transition to a single semantic level with the author, narrator or characters. This is possible through the use of the personal pronoun WE in the sense of «I-Narrator + You-Author + You-Reader», the use of verbs in the form of the first person plural, the use of the phenomenon to metalepsis, the use of wordsmarkers of contact support, and others. The main is the assimilation of the contentsemantic part of the work that fully meets the requirements of truthfulness reflect the biography of the outstanding personality of the past or of the present.

In the associative-psychological type of content-semantic biographies (as «Saxaul in the Sand» by Roman Ivanychuk, «Long Road by Night» by Mariian Krasutskii, «The Action in the Fifth Dimension» by Bohdan Pevnyi, «Treasures of the Earth Warmed» by Vasyl Hubarets and Ivan Padalka, «Storonets» by Roman Andriiashyk, and others) for a better understanding of the psychology of the character the author introduces in his partly fictional story in which an outstanding personality arises 
against the background of the modern era in the real historical, social and cultural environment.

For this narrative type is characteristic the literary forms of the protagonist's life, the disengagement of the author in the text level, distancing of narrator from the fable space works, the disclosure of the inner world of the hero through the image narrator that is the bearer of the author's intentions, and through a complex system of relations with the outside world, indirect impact through the selection of outstanding figures, which should be a role model, and through a shared ideological and stylisticemotional tone of the work.

One of the varieties of this kinds of biographies is the associative-psychological literary biographies in which the mysteries of your own soul tries to understand the hero of biographical works (for example, «Confession on Top» by Ihor Muratov, «I, Bohdan» by Pavlo Zahrebelnyi, «Court» by Hryhorii Shton). The hero is opposed to the author for social characteristics and acts as both object and subject of the narrative. And it is through the prism of his mind replayed the events described in the novel.

In the formalized literary biographies (as «A Poet from the Banks of the Rhein. The Life and Suffering of Heinrich Heine» by Lev Kopelev, «Gabriel Garcia Marquez. The path to Glory» by Yurii Paporov, «Twelve Hoops» by Yurii Andrukhovych, «El club Dumas or La sombra de Richelieu» by Arturo Pérez-Reverte, «The Da Vinci Code» by Dan Brown, «Im Krebsgang» by Günter Grass, «Baudolino» by Umberto Eco, and others) the main focus is on the dynamics of the form. The reader recognizes the equal and becomes an equal participant in the author's games are not only with their own text or texts, but with texts of other authors. The author can access the game on the form (combining in one work the associative-psychological and plot-event biographies, which complement and mutually enrich each other), but most of all - the game not only with the form and the content of literary-biographical works.

In the second case, the real biography of an outstanding personality becomes the key to understanding the plot of a fictional story and can be secondary to the fictitious biography of a fictional or legendary character that is at the forefront of the biographical narration.

Basically is a combinatorial game, the author not only with the reader of the literarybiographical works, but also with their own text (texts) and texts of other authors. 
The author creates an alternate or fictitious biography of the outstanding personality of the past, is the pages works in the form of separate biographems or fragmented semantic blocks; reproduces the multiplicity of the interpretation of the image of the outstanding personality; seamlessly interweaves truth and fiction; combines in a single text space two or more texts: the fictional novel world and the real or alternative biography of a real historical figure, the main text of the work and mise en abyme, «its» text (texts) and texts of other authors.

In this variant of literary biographies, the reader is invited to join the author's game with the collection of biographical mosaic into a single organic whole; the separation of truth from fiction in an alternate and fictitious biographies by conducting their own biographical investigation; research of spitefulness of two or more texts in the same space (we are talking about metatextual and hypertextual games); search the texts of other authors and to elucidate their role in the author's text (intertextual games).

Thus, literary-biographical prose, which is implemented in numerous genre and typological forms, shows a high degree of activity of the author and the reader at the text level. The installation of the narrative contact, the formation of the reader's horizon of expectations, conclusion of the reader's narrative contract occurs at the level of peritext. Means of keeping contact actively used in the main text of literary biography (the use of pronouns and verbs in the first person plural, the use of the phenomenon to metalepsis, etc.). This is implemented in the communicative direction of literary-biographical prose.

\section{REFERENCES}

«Биографии и контрбиографии» (2000). Иностранная литература, № 4, cc.274-279.

Галич, A. А. (1984). Современная художественная документальнобиографическая проза (Проблемы развития жанров). Канд. наук, АН УССР Ин-т л-ры им. Т. Г. Шевченко.

Галич, О. (2015). Глобалізація і квазідокументальна література. Рівне: ЛНУ імені Тараса Шевченка; видавець О. Зень.

Галич, О. А. (2013). Fiction $i$ non fiction y літературі: проблеми теорії та icmopiï. Луганськ: СПД Рєзніков В. С. 
Карачова, Д. В. (2016). Вікторіанська біографія та ї̈ модифікація в XX столітті. Канд. наук, ДЗ «Луганський національний університет імені Тараса Шевченка».

Черкашина, Т. Ю. (2009). Наративні виміри художньо-біографічної прози. Луганськ: СПД Рєзніков В. С.

Шевердіна, А. П. (2014). Жанрові модифікаиї художньої біографії (на матеріалі украӥнської прози кіния XX - початку XXI століття). Канд. наук, ДЗ «Луганський національний університет імені Тараса Шевченка».

Современное зарубежное литературоведение. Страны Западной Европьи и США. Концепции, иколь, термины. Энциклопедический справочник (1999), 2-е изд., испр. и доп. М.: Интрада - ИНИОН.

Boyer-Weinmann, M. (2005). La relation biographique: enjeux. Seyssel: Champ Vallon.

Cline, S. and Angier, C. (2010). The Arvon Book of Life Writing: Writing Biography, Autobiography and Memoir. London: A\&C Black.

Life Writing: Autobiography, Biography and Travel Writing in Contemporary Literature: Proceedings of a Symposium Held by the Department of American Culture and Literature Haliç University, Istambul, 19 - 21 April 2006 (2007). Stuttgart: Ibidem-Verlag, 2007.

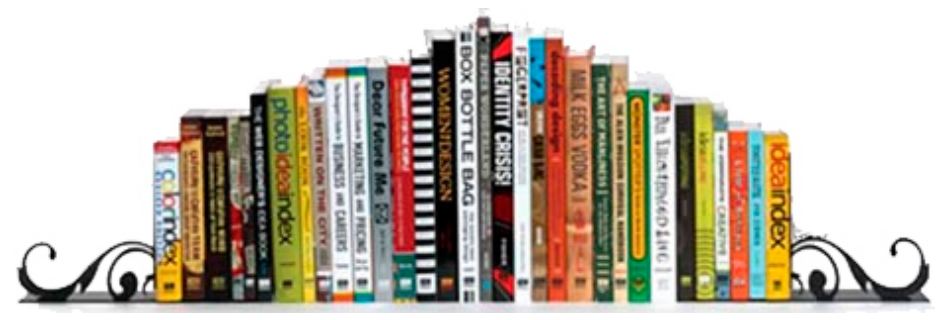

